\title{
Etiology and treatment of the noncarious cervical lesions - literature update
}

\author{
Etiologia şi tratamentul leziunilor cervicale noncarioase - \\ update din literatură
}

\author{
Smaranda Buduru1, Antoine Muth1, Silvia Balhuc1, Rareş Buduru², Mihai Mitariu³, \\ Marius Negucioiu', Elina Teodorescu ${ }^{4}$, Andreea Kui ${ }^{1}$ \\ ${ }^{1}$ Catedra de Protetică Dentară, UMF „Iuliu Haţieganu“, Cluj-Napoca, România \\ ${ }^{2}$ Clinica Stomestet, Cluj-Napoca, România \\ ${ }^{3}$ Catedra de Chirurgie Dento-Alveolară, Universitatea „Lucian Blaga“, Sibiu, România \\ ${ }^{4}$ Disciplina de Ortodonţie, UMF „Carol Davila“, Bucureşti, România
}

\begin{abstract}
REZUMAT
Scopul acest studiu a fost de a revizui literatura de specialitate vizavi de leziunile cervicale noncarioase (LCNC) Material şi metodă. Articole relevante au fost căutate elctronic în bazele de date Pubmed şi Embase, după următoarele asocieri de cuvinte cheie: „leziuni cervicale noncarioase“, „uzură dentară“, „abfracţie“, „stres ocluzal“, „ocluzie dentară“. Studiul a inclus articole scrise în limba engleză publicate între anii 1991 şi 2020.

Rezultate. Căutarea iniţială a generat 186 de articole, dintre care doar 69 au fost incluse în studiu, ele îndeplinind criteriile de includere. Leziunile cervicale noncarioase au o etiologie multifactorială, ceea ce implică un examen clinic oral minuţios realizat şi un plan de tratament corect.

Concluzii. Nu există o confirmare specifică a strategiilor de tratament autentice şi de succes pentru aceste leziuni de abfracţie. Cu toate acestea, literatura de specialitate pune un accent deosebit pe examinarea clinică complexă (cu scopul de a identifica factorii etiologici ai LCNC), asociată cu elaborarea unui plan de tratament adaptat diagnosticului complet al pacientului.
\end{abstract}

Cuvinte cheie: leziuni cervicale noncarioase, uzură dentară, abfracţie, stres ocluzal, ocluzie

\begin{abstract}
The aim of this study was to assess the literature in the field regarding the non-carious cervical lesions (NCCL). Material and method. Relevant articles were electronically search in Pubmed and Embase data base using the following key words: "non-carious cervical lesions", "dental wear", "abfractions", "occlusal stress", "dental occlusion". Articles published in english between 1990 and 2018 were included.

Results. The initial search generated 86 articles but only 69 were included in the study due to the inclusion criteria. NCCL have a multi-factor aetiology which implies a very thorough clinical examination and subsequently a correct treatment plan.

Conclusions. There is not a confirmation for a specific treatment strategy for abfractions. Nevertheless, the literature in the field emphasise the need for a complex clinical examination (in order to identify the etiological factors) and a treatment plan should be modulated after the complete diagnosis of the patient.
\end{abstract}

Keywords: non-carious cervical lesions, dental wear, abfractions, occlusal stress, dental occlusion

\section{INTRODUCERE}

Uzura dinţilor sau pierderea de substanţă dură dentară în absenţa cariei dentare este considerată a fi rezultatul a două mecanisme importante - mecanic şi chimic $(1,2)$. În etiologia acestor leziuni, o multitudine de factori mecanici extrinseci sunt luaţi în considerare, precum masticaţia alimentelor dure, periajul dentar intempestiv, interpunerea diferitelor obiecte între arcadele dentare; cu toate acestea, anumite leziuni pot apărea ca rezultat al acţiunii chimice a unor compuşi asupra smalţului dentar sau chiar ca urmare a unei ocluzii dentare defectuoase (2).

În literatura de specialitate, leziunile de uzură au fost clasificate în patru categorii: abrazia dentară, 
atriţia, abfraţia şi eroziunea dentară. Atriţia este considerată a fi uzura fiziologică a suprafeţelor ocluzale şi a marginilor incizale ca urmare a acţiunii antagoniste a dinţilor prezenţi pe cele două arcade dentare, fiind un proces lent, dar constant şi proporţional cu vârsta pacientului. Atunci când leziunile de uzură dentară sunt cauzate ca urmare a interpunerii anumitor obiecte între arcadele dentare sau ca urmare a unui periaj intempestiv, a unei masticaţii unilaterale sau doar pe un număr limitat de dinţi, acestea sunt considerate abrazie dentară. Eroziunea este considerată a fi uzură dentară de natură chimică, iar compuşii chimici cauzatori sunt fie extrinseci (consumul de substanţe acide: sucuri de citrice, sucuri carbogazoase etc.), fie intrinseci (compuşii chimici provin de regulă din sucurile gastrice, ca urmare a unui reflux gastroesofagian sau a altor patologii care implică vărsături frecvente) (2).

Termenul de abfracţie dentară a fost menţionat pentru prima dată de către Grippo în anul 1991 (3) şi este definit ca o leziune de uzură dentară, care apare de regulă la nivel cervical, pe suprafeţele vestibulare ale dinţilor (atât anteriori, cât şi posteriori). Teoria abfracţiei dentare susţine faptul că aceste leziuni sunt determinate de stresul fizic cauzat de acţiunea unor forţe paraxiale (relaţii ocluzale defectuoase) asupra zonei cervicale a dintelui, forţe care, în timp, reuşesc să rupă legăturile dintre cristalele de hidroxiapatită, rezultând microfracturi în smaţul dentar. Aceste micro-fracturi vor favoriza pierderea de substanţă dentară în regiunea cervicală. Această teorie legată de abfracţie este susţinută de numeroase studii publicate în literatura de specialitate, mai ales de anumite cercetări făcute pe pacienţi cu bruxism, care au prezentat astfel de leziuni cu o frecvenţă mai crescută faţă de pacienţii fără bruxism (4).

$\mathrm{Cu}$ toate acestea, anumite studii sugerează faptul că etiologia abfracţiei dentare este încă neelucidată, în condiţiile în care leziunile apar cu preponderenţă pe feţele vestibulare ale dinţilor şi foarte rar pe feţele linguale. De asemenea, un studiu clinic prospectiv a relevat faptul că, în urma reechilibrării ocluzale, aceste leziuni cervicale au progresat (5).

Scopul acestui studiu este acela de a revizui literatura de specialitate pentru a putea distinge cauzele leziunilor cervicale noncarioase (LCNC), implicit ale abfracţiei dentare, dar şi de a evidenţia metodele de tratament actuale în cazul acestei patologii.

\section{MATERIAL ŞI METODĂ}

Pentru realizarea acestui studiu tip review de literatură, doi cercetători au efectuat o căutare a articolelor relevante pentru tema aleasă. Au fost căutate articole relevante utilizând bazele de date Pubmed şi Embase. Strategia de căutarea s-a făcut utilizând următoarele combinaţii de cuvinte cheie: „leziuni cervicale noncarioase“, „uzură dentară“, „,abfracţie“, „,stres ocluzal“, „ocluzie dentară“. Motorul de căutare s-a limitat la articole scrise în limba engleză publicate între anii 1991 şi 2020.

Articolele au fost selectate pe baza următoarelor criterii de includere: studii clinice sau de laborator, care s-au concentrat pe felul în care stresul a fost incriminat ca factor cauzator pentru leziunile cervicale noncarioase, precum şi diferitele perspective vizavi de tratamentul adjuvant al acestor leziuni.

Au fost excluse următoarele tipuri de articole: articole sub formă de rezumat, fără a se găsi conţinutul întreg al acestora, articole irelevante pentru tema de studiu aleasă.

\section{REZULTATE}

S-a efectuat o primă căutare a articolelor pe baza cuvintelor cheie, ceea ce a generat un număr de 186 de articole cu potenţial eligibil, dintre care 97 în PubMed şi 89 în baza de date Embase. Dintre articolele găsite, 83 de articole au fost identificate ca duplicate şi, ulterior, au fost şterse, apoi cele 103 articole rămase au fost verificate pe baza titlului, a cuvintelor cheie şi a rezumatelor. În urma unei noi analize a titlurilor şi a rezumatelor, au fost excluse 34 de articole deoarece concluziile lor nu erau relevante pentru cercetarea noastră.

Dintre cele 69 de articole incluse, 31 au fost studii clinice şi 38 studii de laborator. Dintre aceste studii, $56(81 \%)$ au raportat o asociere între stresul ocluzal şi LCNC, în timp ce în rest, în celelalte 13 studii (19\%), s-au obţinut rezultate neconcludente sau contradictorii.

\section{DISCUṬII}

În total, 56 de studii susţin teoria abfracţiei dentare, faptul că aceste leziuni sunt cauzate de stresul 


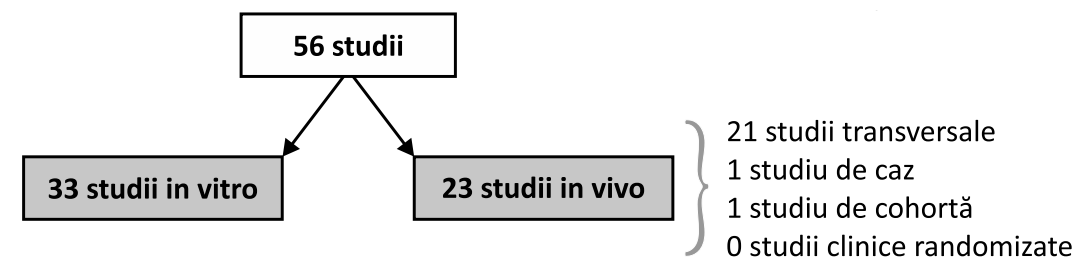

FIGURA 1. Numărul de studii care susțin teoria abfracției dentare

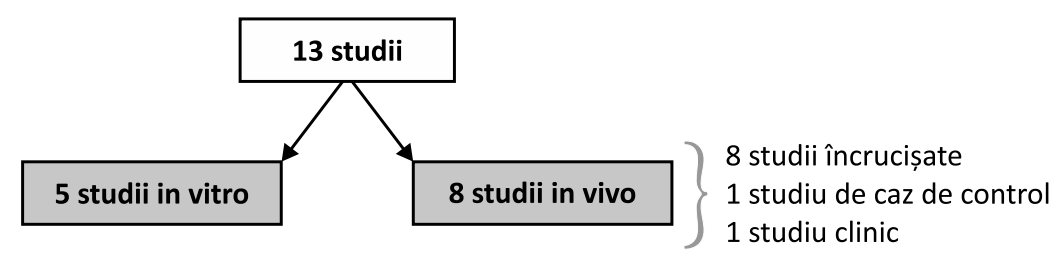

FIGURA 2. Articole care nu susțin teoria abfracției dentare

fizic generat de relaţii ocluzale defectuoase (obiceiuri parafuncţionale, ghidaje sau relaţii ocluzale defectuoase) (fig. 1). Numărul total de subiecţi prezenţi în studiile care confirmă teoria abfracţiei a fost de 3.908, cu vârste între 15 şi 80 de ani. Legat de numărul pacienţilor din eşantioanele luate în considerare în studii, s-a observat faptul că acesta variază între 6 şi 2.386, eşantioanele mici (mai puțin de 100 de subiecţi) fiind cel mai frecvent întâlnite.

Romeed sugerează în studiul de cohortă faptul că ar exista o posibilă relaţie de cauzalitate între prezenţa faţetelor de uzură ocluzale şi leziunile cervicale noncarioase; în acest context, autorii sugerează că apariţia leziunilor cervicale ar fi la aproximativ trei ani de la decelarea suprafeţelor ocluzale de uzură (6).

Dintre cele 33 de studii in vitro, 24 au folosit diferite metode informatice, precum "occlusal fingerprint analyser" (OFA), pentru a anticipa răspunsul şi comportamentul structurilor dentare afectate de stres mecanic. Alte 9 studii au utilizat tomodensitometrie şi tomografie prin coerenţa optică pentru a obţine imagini de microstructură ale LCNC (7). În urma analizei în laborator, pe modele, cele mai frecvente faţete de abrazie apar în cazul premolarilor. Toate studiile care au folosit metode informatice de cuantificare a datelor au relevat faptul că presiunea ocluzală dezvoltă un stres asupra regiunii cervicale indiferent de tipul şi direcţia forţei (8).

Un studiu in vitro, condus de Grippo, a evidenţiat efectele suplimentare ale eroziunii acide (produsele utilizate au fost acid clorhidric $\mathrm{pH}=0,1$ şi suc de portocale $\mathrm{pH}=4$ ) pe dinţii supuşi unor cicluri de stres mecanic ( 72 cicluri/min, total 9.200 de cicluri) asupra profunzimii LCNC pe premolarii extraşi. Dinţii care au primit o şarjă de stres chimic au prezentat leziuni semnificativ mai profunde decât dinţii din studiul de control (9).

Tot în acest context, alte două studii au analizat acţiunea combinată (mecanică şi chimică) asupra gravităţii leziunilor cervicale noncarioase. Staninek a studiat efectele biocoroziunii ( $\mathrm{pH}$ uşor acid $=$ 6 sau neutru $=7)$ şi ale stresului mecanic $(5,5$ până la 55 megapascali, 2 hertzi, 1 milion de cicluri) asupra pierderii de dentină. Palamara a demonstrat că dizolvarea acidă ( $1 \%$ acid lactic, ph 4,5, timp 28 de ore) a LCNC a fost afectată de încărcările ocluzale ciclice (100 de N, 2 HtZ, 200.000 cicluri) $(9,10,11)$.

$\mathrm{Au}$ fost identificate 13 articole care nu susţin teoria abfracţiei dentare (fig. 2). Numărul total de subiecţi prezenţi în studiile care infirmă teoria abfracţiei a fost 924, cu vârste între 14 şi 80 de ani. Numărul pacienţilor din eşantioane variază între 30 şi 299, jumătate din studiile incluse având eşantioanele de pacienţi cu mai puţin de 100 de pacienţi.

Doar în 5 studii clinice (din totalul de 8) s-au menţionat criteriile de includere şi excludere utilizate pentru recrutarea pacienţilor; 5 studii au recrutat subiecţii dintre pacienţii care s-au prezentat în serviciile de medicină dentară, iar 1 studiu dintr-un grup de studenţi la medicină dentară; 2 studii nu au specificat cum s-a făcut recrutarea subiecţilor. Rezultatele celor 5 studii in vitro asupra caracteristicilor morfologice ale leziunilor noncarioase pe dinţi umani extraşi nu au fost concludente pentru a susţine teoria abfracţiei.

Un alt studiu experimental a remarcat că aplicarea de forţe ocluzale nu a afectat dezvoltarea LCNC 
pe dinţii cu abrazii cauzate de periuţa de dinţi (12).

Două studii prospective au fost analizate în realizarea acestui review de literatură. Unul dintre ele a avut o durată de 3 ani şi a observat LCNC la 40 de studenţi la medicină dentară. Ambele articole concluzionează că există o asociere între faţetele de uzură şi dezvoltarea $\operatorname{LCNC}(13,14)$.

Studiile de laborator au sugerat că LCNC sunt rezultatul stresului şi mecanismul combinat de degradare descris de Grippo provoacă iniţierea şi perpetuarea altor mecanisme ale leziunilor respective. Rezultatele obţinute sugerează faptul că relaţia cauză-efect este consecventă, în funcţie de situaţie, şi anume stresul fizic va determina abfracţie, frecarea va determina uzura dinţilor pe suprafeţele ocluzale şi biocoroziunea va determina leziuni de eroziune chimică, dar şi că toate acestea au capacitatea de iniţiere şi perpetuare a altor leziuni cervicale noncarioase $(15,16)$.

Bartlett şi Shah au sugerat că LCNC este de origine multifactorială, posibilitatea ca stresul ocluzal să determine leziuni cervicale nu poate fi eliminată, deoarece efectul său asupra formării leziunilor este dificil de evaluat prin studii clinice $(10,11,17)$.

În studiile de laborator, "occlusal fingerprint analyser" (OFA) s-a dovedit a fi metoda cel mai des utilizată pentru a studia efectul forţelor de încărcare ocluzală asupra dezvoltării LCNC. OFA este o metodă informatizată care permite anticiparea răspunsului sau comportamentul structurilor dentare afectate de stresul mecanic. Ea poate rezolva, de asemenea, probleme mecanice complicate. Totuşi, ecuaţiile matematice corespunzătoare sunt necesare pentru a prezice răspunsul real al structurilor dentare. A fost găsită o mare variaţie a valorilor modulului Young: valorile modulului Young al smalţului au variat între 87.500 şi $46.900 \mathrm{MPa}$, în timp ce valorile dentinei sunt cuprinse între 19.800 şi $15.000 \mathrm{MPa}$ (18).

Toate studiile incluse în această revizuire care au utilizat OFA au susţinut că abfracţia este un posibil mecanism de a provoca LCNC, faţă de alte studii de laborator care au avut rezultate contradictorii. Dintre studiile de laborator, studiile observaţionale au fost mai frecvente decât studiile experimentale. Patru studii de laborator au raportat dovezi ale abfracţiei. Din cauza numărului mic de studii experimentale, este posibil ca regiunea cervicală a dinţilor să fie susceptibilă la leziuni de abraziune datorate oboselii, stresului şi expunerii la acizii din condiţiile de laborator $(15,16,19)$.

Rezultatele multor cercetări acceptă ipoteza de la care am pornit în realizarea acestui review de literatură - şi anume că factorii ocluzali au fost asociaţi cu prezenţa LCNC. Cu toate acestea, mulţi autori remarcă faptul că forţele de tensiune mai mici din mişcările laterale nu reduc/împiedică progresia leziunea. Acest rezultat confirmă faptul că, deşi tensiunile create în laborator sunt mai slabe dacă nu sunt axiale, interferenţa ocluzală continuă să acţioneze, promovând progresia leziunilor. Interferenţa ocluzală în intercuspidarea maximă şi în apropierea zonei nefuncţionale sunt, de asemenea, factori de risc pentru dezvoltarea LCNC. Trebuie menţionat faptul că mişcarea de propulsie adecvată este deseori corelată cu absenţa leziunilor, adică pacienţii fără leziuni au interferenţe mai puţine în ghidajul anterior (15).

Frecvenţa faţetei de uzură în grupurile incisive ar putea să fie legată de frecvenţa crescută a obiceiurilor parfuncţionale. Obiceiurile parafuncţionale sunt mai frecvente la pacienţii cu LCNC; sarcina ocluzală generată de aceste obiceiuri este mai mare decât încărcăturile axiale, cauzând leziuni semnificative ale ţesuturilor dentare. Masticaţia unilaterală nu a fost asociată cu prezenţa leziunilor (20).

Potrivit studiilor incluse, majoritatea (56 de articole din $69,81 \%$ ) au adus dovezi care să sprijine asocierea dintre LCNC şi stres (16,21).

Legat de modalităţile de tratament pentru leziunile cervicale noncarioase, studiile publicate până în acest moment recomandă prevenţia prin modificarea dietei, a metodei de periaj, folosirea gutierelor nocturne de bruxism, folosirea gumei de mestecat pentru creşterea debitului secreţiei salivare şi/ sau elaborarea unui potenţial tratament medical intrinsec sau psihoterapie (21).

O altă abordare terapeutică ar fi monotorizarea leziunilor cervicale noncarioase. Uzura dinţilor este privită ca un proces fiziologic, de aceea se indică monotorizarea acestor leziuni, iar tratamentul prin restaurare trebuie să ţină cont de vârsta pacientului şi de vitalitatea dinţilor. În cazul leziunilor de abrazie accentuate, pentru dinţii afectaţi s-ar putea indica, de asemenea, alongări chirurgicale asociate ulterior cu reconstrucţii protetice de tipul coroanelor de acoperire sau proteze parţiale fixe. 
În majoritatea cazurilor, pacienţii nu acuză acuze sensibilitate dentinară şi nici afectarea funcţiei esteticii, de aceea, în general, se urmăreşte monotorizarea LCNC la intervale de timp de 6-12 luni, fără alte intervenţii, în situaţiile în care lipsa de substanţă dură nu depăşeşte 1 mm (22).

Terapia ocluzală prin ajustare are ca scop şlefuiri selective cu scopul de a elimina contactele şi interferenţele premature şi de a obţine relaţii ocluzale stabile şi funcţionale. Se examinează poziţia mandibulei, intercuspidarea maximă, relaţiile de ocluzie statică la nivelul incisivilor, caninilor şi primilor molari, curbele ocluzale şi gradul de cuspidare al dinţilor. Examinarea completă trebuie să cuprindă identificare interferenţelor ocluzale şi parafuncţiile orofaciale (23-25). Ajustările ocluzale necorespunzătoare pot provoca iniţierea cariilor dentare, uzura dinţilor şi hipersensibilitate dentinară. Pentru a evita forţele ocluzale necorespunzătoare, literatura de specialitate recomandă purtarea unor dispozitive de protecţie (gutiere) pentru a minimiza iniţierea LCNC (26).

Hipersensibilitatea dentinară este primul simptom al LCNC, dar acesta poate apărea mai târziu deoarecere procesul de abrazie este lent şi cronic asociat cu un proces de remineralizare dentinară. Tratamentele noninvazive presupun aplicarea de desensibilizanţi, de lacuri cu fluor sau utilizarea pastelor de dinţi desensibilizante (26).

Tratamentul restaurativ al leziunilor de uzură se face uneori cu dificultate din cauza contaminării prin umiditate, acces dificil la limitele subgingivale şi incapacitatea de a trata dentina sclerotică (26-28).

$\mathrm{Nu}$ există dovezi legate de faptul că tratarea leziunilor prin tehnici de restaurare opreşte evoluţia
LCNC; de aceea, se recomandă să se respecte următoarele condiţii pentru alegerea acestei metode de tratament: prezenţa cariilor active însoţite de leziunile abrazive, leziunile localizate pe marginile cervicale şi/sau subgingival, care impiedică controlul plăcii bacteriene cu risc crescut de apariţie de carii şi parodontită marginală, dinţi cu una sau două defecte în suprafaţă, pierderea integrităţii dinţilor şi/sau pulpei dentare la care tratamentele noninvazive au eşuat, atunci când sunt necesare reconstituiri protetice ce implică dinţii afectaţi de LCNC sau la cererea pacientului (29).

\section{CONCLUZII}

Leziunile cervicale noncarioase (LCNC) au o etiologie multifactorială. Există o legătură între diferiţii factorii etiologici şi factorii favorizanţi ai pacientului care ar putea duce la iniţierea şi progresia diferitelor leziuni de abrazie şi diferitelor aspecte clinice. Studiile publicate în acest sens pun in evidenţă faptul că există o asociere între stresul ocluzal şi leziunile cervicale noncarioase. Obiceiurile parafuncţionale, cum ar fi încleştarea dinţilor, dar şi relaţiile ocluzale defectuoase reprezintă factori de risc pentru apariţia şi dezvoltarea LCNC. Nu există o confirmare specifică a strategiilor de tratament autentice şi de succes pentru aceste leziuni de abfracţie. $\mathrm{Cu}$ toate acestea, literatura de specialitate pune un accent deosebit pe examinarea clinică complexă (cu scopul de a identifica factorii etiologici ai LCNC), asociată cu elaborarea unui plan de tratament adaptat diagnosticului complet al pacientului.

\section{BIBLIOGRAFIE}

1. Haralur SB, Alqahtani AS, AlMazni MS, Alqahtani MK. Association of Non-Carious Cervical Lesions with Oral Hygiene Habits and Dynamic Occlusal Parameters. Diagnostics (Basel). 2019 Apr 12;9(2).

2. Rusu Olaru A, Popescu MR, Dragomir LP, Popescu DM, Arsenie CC, Rauten AM.Identifying the Etiological Factors Involved in the Occurrence of Non-Carious Lesions. Curr Health Sci J. 2019 Apr-Jun;45(2):227-234.

3. Grippo JO. Abfractions: A new classification of hard tissue lesions of teeth. J Esthet Dent. 1991;3(1):14-9.(30)

4. Nascimento MM, Dilbone DA, Pereira PN, Duarte WR, Geraldeli S, Delgado AJ. Abfraction lesions: Etiology, diagnosis, and treatment options. Clin Cosmet Investig Dent. 2016 May 3;8:79-87.

5. Atalay C, Ozgunaltay G. Evaluation of tooth wear and associated risk factors: A matched case-Control study. Niger J Clin Pract. 2018 Dec;21(12):1607-1614.

6. Romeed SA, Malik R, Dunne SM. Stress analysis of occlusal forces in canine teeth and their role in the development of non-carious cervical lesions: abfraction. Int J Dent. 2012; 2012:234845.

7. Stefano Benazzi, Huynh Nhu Nguyen, Ottmar Kullmer, and Kornelius Kupczik. Dynamic Modelling of Tooth Deformation Using Occlusal Kinematics and Finite Element Analysis. Published online $2016 \mathrm{Mar}$ 31.

8. John O Grippo, Marvin Simring, Thomas A Coleman Abfraction, Abrasion, Biocorrosion, and the Enigma of Noncarious Cervical Lesions: A 20-Year Perspective. J Esthet Restor Dent 2012, 24 (1)10.

9. John O Grippo, Marvin Simring, Steven Schreiner, Attrition, Abrasion, Corrosion and Abfraction Revisited: A New Perspective on Tooth Surface Lesions. J Am Dent Assoc 2004, 135 (8):1109-18.

10. Palamara D1, Palamara JE, Tyas MJ, Pintado M, Messer HH. Effect of stress on acid dissolution of enamel. Dent Mater. 2001 Mar;17(2):109-15. 
11. Munari LS, Cornacchia TP, Moreira AN, Gonçalves JB, De Las Casas $\mathrm{EB}$, Magalhães CS. Stress distribution in a premolar 3D model with anisotropic and isotropic enamel. Med Biol Eng Comput. 2015 Aug;53(8):751-8.

12. Shrestha $D$, Rajbhandari P. Prevalence and Associated Risk Factors of Tooth Wear. JNMA J Nepal Med Assoc. 2018 JulAug;56(212):719-723.

13. Haralur SB, Alqahtani AS, AIMazni MS, Alqahtani MK.Association of Non-Carious Cervical Lesions with Oral Hygiene Habits and Dynamic Occlusal Parameters. Diagnostics (Basel). 2019 Apr 12;9(2).

14. Chai Kit Lu, Margaret Chia Soo Yee, Spoorthi Banavar Ravi, and Rohit Pandurangappa.Forensic Age Estimation of Chinese Malaysian Adults by Evaluating Occlusal Tooth Wear Using Modified Kim's Index. Int J Dent. 2017; 2017: 4265753.

15. Yang J, Cai D, Wang F, He D, Ma L, Jin Y, Que K. Non carious cervical lesions (NCCLs) in a random sampling community population and the association of NCCLs with occlusive wear. J Oral Rehabil. 2016 Dec;43(12):960-966.

16. Peter Wetselaar, Daniele Manfredini, Jari Ahlberg, Anders Johansson, Ghizlane Aarab, Chryssa E. Papagianni, Marisol Reyes Sevilla, Michail Koutris, Frank Lobbezoo. Associations between tooth wear and dental sleep disorders: A narrative overview. J Oral Rehabil. 2019; 46(8):765-775.

17. Marinescu IR, Popescu SM, Răghici EC, Scrieciu M, Mercuţ V, Turcu AA, Nicola AG Etiological Aspects of Noncarious Dental Lesions. Curr Health Sci J. 2017 Jan Mar;43(1):54-61.

18. Igarashi Y, Yoshida S, Kanazawa E.The prevalence and morphological types of non-carious cervical lesions (NCCL) in a contemporary sample of people. Odontology. 2017 Oct;105(4):443452 .

19. Jakupović S, Anić I, Ajanović M, Korać S, Konjhodžić A, Džanković A, Vuković A.Biomechanics of cervical tooth region and noncarious cervical lesions of different morphology; three-dimensional finite element analysis. Eur J Dent. 2016 Jul-Sep;10(3):413-418.

20. Miller N, Penaud J, Ambrosini P, Bisson-Boutelliez C, Briançon S. Analysis of etiologic factors and periodontal conditions involved with 309 abfractions. J Clin Periodontol. 2003;30(9):828-32.

21. Assunção CM, Schlueter N, Rodrigues JA, Carvalho TS, Lussi A. Do fluoride toothpastes have similar preventive effect in permanent and primary teeth against erosive tooth wear? Int J Paediatr Dent. 2018 Nov 15.

22. Yang S, Lee H, Jin SH. A combined approach to non-carious cervical lesions associated with gingival recession. Restor Dent Endod. 2016;41(3):218-24.

23. Peck CC. Biomechanics of occlusion - implications for oral rehabilitation. J Oral Rehabil. 2016 Mar;43(3):205-14.

24. Pegoraro LF, Scolaro JM, Conti PC, Telles D, Pegoraro TA. Noncarious cervical lesions in adults Prevalence and occlusal 90 aspects. J Am Dent Assoc. 2005;136(12):1694-700.

25. Green JI. Prevention and Management of Tooth Wear: The Role of Dental Technology. Prim Dent J. 2016 Aug 1;5(3):30-33.

26. Longridge NN, Youngson CC. Dental Pain: Dentine Sensitivity, Hypersensitivity and Cracked Tooth Syndrome. Prim Dent J. 2019 May 20;8(1):44-51.

27. Anhesini BH, Landmayer K, Nahsan FPS, Pereira JC, Honório HM, Francisconi-Dos-Rios LF. Composite vs. ionomer vs. mixed restoration of wedge-shaped dental cervical lesions: Marginal quality relative to eccentric occlusal loading. J Mech Behav Biomed Mater. 2019 Mar;91:309-314.

28. Coe J. Which adhesive strategy for non-carious cervical lesions? Evid Based Dent. 2017 Dec 22;18(4):119-120.

29. Freitas Sda S, Sousa LL, Moita Neto JM, Mendes RF, Prado RR. Dentin hypersensitivity treatment of non-carious cervical lesions - a single-blind, split-mouth study. Braz Oral Res. 2015;29:45.

\section{Conflict of interest: none declared}

Financial support: none declared 